\title{
EDITORS' REPORT
}

This "insurance economics" issue of The Geneva Papers on Risk and Insurance is, except for one invited paper, composed with papers submitted to the refereeing process. Three of these paper were submitted in 1987 and one in 1988.

The status of the three 1987 papers which had been returned for major revision as of March 1988 is as follows:

- Accepted 1

- No response from author 2

Total $\overline{3}$

Only nine new manuscripts were submitted in 1988. As of January 1,1989 , their status is as follows:

- Not suitable 2

- Accepted after minor revision 1

- Accepted after major revision -

- Returned for major revision 1

- Still under review 5

Total $\overline{9}$

For 1988 the editors gratefully acknowledge the help of the following referees:

- Gerhard BERZ

- George BLAZENKO

- Dongsae CHO

- Stephen D'ARCY

- Georges DIONNE
- Don FRIEDMANN

- Jean LEMAIRE

- Jean-François OUTREVILLE

- Jean-Charles ROCHET

- Steven SHAVELL

- Emilio VENEZIAN. 